\title{
Bouguer Density Analysis using Nettleton Method at Banten NPP Site
}

\author{
Yuliastuti $^{\star}$, Hadi Suntoko, Yarianto S.B.S
}

Pusat Kajian Sistem Energi Nuklir, Badan Tenaga Nuklir Nasional, Jl. Kuningan Barat, Mampang Prapatan,Indonesia

\begin{tabular}{|c|c|}
\hline $\begin{array}{l}\text { ARTICLE } \\
\text { INFORMATION }\end{array}$ & ABSTRACT \\
\hline $\begin{array}{l}\text { Article History: } \\
\text { Received: } \\
\quad 14 \text { June } 2017 \\
\text { Received and revised form: } \\
20 \text { June } 2017 \\
\text { Accepted: } \\
\quad 20 \text { June } 2017\end{array}$ & $\begin{array}{l}\text { BOUGUER DENSITY ANALYSIS USING NETTLETON METHOD AT BANTEN NPP SITE. } \\
\text { Sub-surface information become crucial in determining a feasible NPP site that safe from } \\
\text { external hazards. Gravity survey which result as density information, is essential to understand } \\
\text { the sub-surface structure. Nevertheless, overcorrected or under corrected will lead to a false } \\
\text { interpretation. Therefore, density correction in term of near-surface average density or Bouguer } \\
\text { density is necessary to be calculated. The objective of this paper is to estimate and analyze } \\
\text { Bouguer density using Nettleton method at Banten NPP Site. Methodology used in this paper is } \\
\text { Nettleton method that applied in three different slices (A-B, A-C and A-D) with density } \\
\text { assumption range between } 1700 \text { and } 3300 \mathrm{~kg} / \mathrm{m}^{3} \text {. Nettleton method is based on minimum } \\
\text { correlation between gravity anomaly and topography to determine density correction. The result } \\
\text { shows that slice A-B which covers rough topography difference, Nettleton method failed. While } \\
\text { using the other two slices, Nettleton method yield with a different density value, } 2700 \mathrm{~kg} / \mathrm{m}^{3} \text { for } \\
\text { A-C and } 2300 \mathrm{~kg} / \mathrm{m}^{3} \text { for A-D. A-C provides the lowest correlation value which represents the } \\
\text { Upper Banten tuff and Gede Mt. volcanic rocks in accordance with Quartenary rocks exist in the } \\
\text { studied area. }\end{array}$ \\
\hline
\end{tabular}

ABSTRAK

ANALISIS DENSITAS BOUGUER MENGGUNAKAN METODE NETTLETON DI TAPAK PLTN BANTEN. Informasi bawah permukaan menjadi krusial dalam menentukan kelayakan tapak PLTN yang aman dari bahaya eksternal. Survey gravitasi yang menghasilkan informasi densitas, penting untuk memahami struktur bawah permukaan. Namun demikian, informasi densitas yang terkoreksi lebih atau kurang akan menyebabkan kesalahan interpretasi. Untuk itu, koreksi densitas dalam bentuk densitas rata-rata dekat permukaan atau densitas Bouguer, penting untuk dilakukan perhitungan. Tujuan penelitian adalah melakukan estimasi dan menganalisis densitas Bouguer menggunakan metode Nettleton di tapak PLTN Banten. Metodologi yang digunakan adalah metode Nettleton yang diaplikasikan pada tiga posisi pemotongan (A-B, A-C dan A-D) dengan asumsi densitas $1700-3300 \mathrm{~kg} / \mathrm{m}^{3}$. Metode Nettleton didasarkan pada nilai korelasi minimum antara anomali gravitasi dan topografi dalam menentukan koreksi densitas Bouguer. Hasil menunjukkan bahwa metode Nettleton gagal pada A-B yang meliputi area topografi yang sangat beragam. Sedangkan pada dua posisi yang lain, metode Nettleton memberikan nilai densitas yang berbeda yaitu, $2700 \mathrm{~kg} / \mathrm{m}^{3}$ untuk A-C dan $2300 \mathrm{~kg} / \mathrm{m}^{3}$ untuk A-D. A-C memberikan nilai korelasi terendah yang merepresentasikan tufa Banten atas dan batuan vulkanik gunung Gede sesuai dengan distribusi batuan Kuarter yang ada di daerah studi.

Kata Kunci: densitas Bouguer, anomali gravitasi, metode Nettleton

\section{INTRODUCTION}

Nuclear Power Plant (NPP) site evaluation is an important stage in NPP infrastructure preparedness. Site evaluation involves various techniques and methods from different sciences. One of the method that plays an important role on investigating site feasibility based on sub-surface information is gravity survey. Sub-surface information become the key point in determining a feasible

*Penulis korespondensi.

E-mail: yuliastuti@batan.go.id
NPP site that safe from external hazards.

In order to understand the sub-surface structure, earth gravitational field is converted into density variation information. Hence, geologist could estimate the sub-surface structure based on this density information [1].

The influence of density variation on gravitational field that being measured is somehow smaller than the influence of altitude and spheroid position factor. There are a large numbers of simplifying assumptions in the 
external gravity correction method which caused some problems, inter alia errors in the Bouguer correction caused by the improper selection of the density and destruction of structure caused by the Bouguer correction[2]. The intention is to have Bouguer anomaly that free from all nongeologic effects[3]. The evaluation of Bouguer anomaly value requires knowledges of station height and surface terrain density since free-air, Bouguer and terrain corrections are proportional to height and/or density [4].

Quantitative analysis of gravity anomalies, therefore, relies heavily on the accuracy of Bouguer reduction density[4]. With the aim of simplifying the calculation, correction on gravity measurement result is typically done by using several assumptions. Some of the assumption applied are relatively flat topographical condition and uniform crustal densities.

For gravity measurement which emphasize on accuracy, such as site evaluation of NPP, appropriate density correction in Bouguer calculation is necessary. Overcorrected or under corrected will lead to a false geological interpretation which could eventually affected the NPP safety.

To interpret gravity anomalies in an extensive area, optimum reduction density as the representative value in the interest area since the gravity reduction is usually made using a constant density based on the assumption that surface and near surface rocks forming the topography have an average density[5]. An error of $0,1 \mathrm{~g} / \mathrm{cm}^{3}$ in the reduction density, corresponding to an error of nearly 0,42 mGal in Bouguer anomaly for every $100 \mathrm{~m}$ [5]. But an error of $0.1 \mathrm{~g} / \mathrm{cm}^{3}$ in the density may have a large effect on the interpretation of Bouguer anomalies.

One of the classic method that could be used to determine density correction or Bouguer density, is Nettleton method. Bouguer density estimation using Nettleton are performed by minimizing the correlation between Bouguer anomaly and topography profile [5].

The objective of this research is to estimate and analyze Bouguer density using Nettleton method at Banten NPP Site. The expected outcome of this paper is to provide preliminary information concerning the parameters that could affect Bouguer density estimation in order to have an accurate subsurface geological interpretation at the studied area. The scope of the research is limited to identify Bouguer density using Nettleton method.

\section{NETTLETON METHOD}

Gravity acceleration commonly depends on five factors namely latitude, elevation, topography, tidal, and density variation of the sub-surface. In order to obtain the accurate image of sub-surface structure, the value of gravity reading should be adjusted. Corrections that should be performed include spheroid correction, free-air correction, Bouguer correction, terrain correction, tidal correction, and isostatic correction. In the condition when all the correction has been performed, then the real value of Bouguer anomaly could be obtained for each measurement station.

Bouguer correction, basically, consider the material interaction which exist between measurement station and datum plane 1 . This correction is performed by using infinite slab approach through the equation [4]:

$$
B C=2 \pi G h \rho
$$

by $\mathrm{G}=6,67 \times 10^{-6} \mathrm{Nm}^{2} / \mathrm{kg}^{2} \cdot\left(\mathrm{mGal} / \mathrm{ms}^{\mathrm{z}}\right), \quad \mathrm{h}$ is elevation (meter), $\rho$ is density $\left(\mathrm{kg} / \mathrm{m}^{3}\right)$ and $\mathrm{BC}$ is Bouguer correction.

From the Eq. 1, accuracy of Bouguer correction is highly sensitive on the choice of gravity reduction density, or often called near-surface average density. Estimation of near-surface average density could be somehow difficult due to the inexistence of unique solution [5]. Telford et al. (1990) refer to $2670 \mathrm{~kg} / \mathrm{m}^{3}$ as the Bouguer density (near-surface average density). This value commonly used based on the assumption that the crustal rock density is uniform.

Nettleton's method is based on the elevation dependence of the surface free-air gravity anomalies and widely used to obtain an optimal average density value by applying e.g. least squares model parameter estimation. Its 
accuracy, however, strongly depends on how efficiently the regional trends and very local (terrain) effects are removed from the gravity anomalies processed[6].

This method is named after L. L. Nettleton, one of the pioneers of applied gravimetry, who realized that no gravity anomalies should remain after the Bouguer correction in an area of constant density. Nettleton's method is based on the observation that over an area of constant density no gravity anomalies should remain after applying the Bouguer correction and that any residual Bouguer anomaly should represent the gravitational attraction of the body of interest[7].

Nettleton's method of determining the reduction density from gravity data can, in some regions, give reasonably satisfactory estimates of an appropriate average nearsurface density for use in Bouguer reduction when the influence of topography needs to be minimized[8]. Nevertheless, the presence of topography is necessary in order to create enough variability so that value which minimizes the correlation of the Bouguer anomaly with topography can be found, but the topographic slopes should be gentle enough to minimize precision errors in the terrain correction.

The use of an appropriate reduction density will remove a correlation of observed gravity with topography[8]. In Nettleton's method, a gravity profile over a study area, in which there are significant sharp variations in elevation, is reduced by using a range of Bouguer reduction densities [8]. The reduction density with a minimum correlation with elevation would give anomalies most representative of the underlying geologic structure [8].

If a studied area is relatively small, the correlation of the topography with regional gravity field could contaminate topographic density estimates[9]. Near surface or reduction density determinations based on Nettleton method can be utilized for estimating representative surface densities where no outcrop or log data exist [10].

\section{METHODOLOGY}

Data used in this paper is the data resulted from 2010-2011 gravity measurement conducted by BATAN. The measurement was done in the term of Site survey of Banten screening stage III (See Figure 1). The data consist of coordinate point for each station (longitude and latitude), elevation, time and date, and gravity reading. The instrument used is gravity meter LaCoste Romberg G-816 and GPS 60cx.

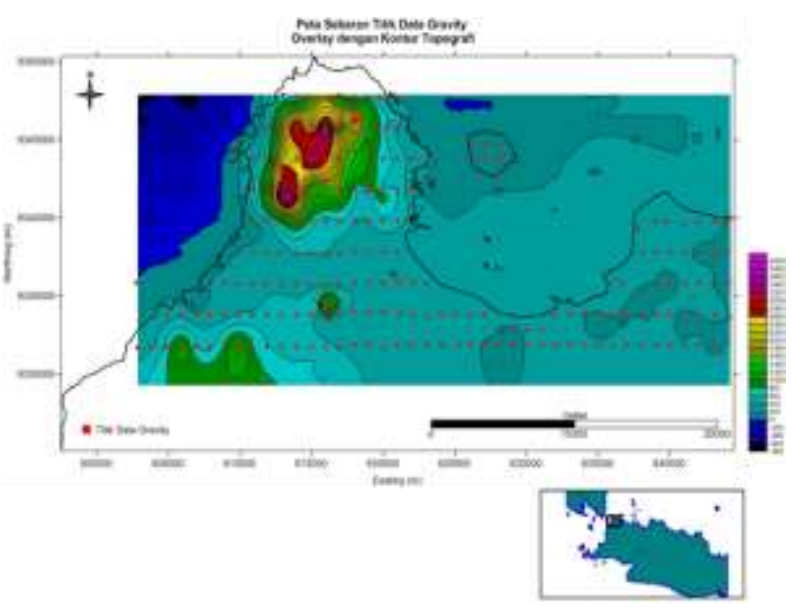

Figure 1 Topographic Profile and Gravity Measurement Station[10].

Banten is located on the southeastern of the margin zone of Late Creataceous Sundaland craton, as part of Sunda volcanic island arc[11]. This volcanic island arc have been active since Upper Mesozoic[11]. Sundaland craton is an active plate margin which moves slowly toward South and marked by a central geanticline[11]. As part of the collision process, magmatic rock intrude the plate margin or has been extruded as lava and volcanoclastic deposit[11]. Those volcanic deposit comprise of several compositions namely basaltic, andesitic and rhyolitic[11]. Volcanic rock in geanticlinal zone is in the form of Deposit volcanoclastic. Volcanic rocks at geanticline zone occur in the form of intercalation between beach sediment, intermontatane and intervolcanic nature[11].

Stratigraphicaly studied area rock formation consist of Bojongmanik Formatian, Cipacar Formation and Bojong Formation. The thickness level of each formation is vary between 200-800 meters[12]. The Miocene Bojongmanik Formation is mostly covered by volcanic deposits, such as the Genteng 
Formation and the Young Volcanic deposit[13]. Based on geological map of Serang \& Anyer[12], the rock distribution in the research area is dominated by volcanic product from Mt. Gunung Gede with the lithology class of lava. Beside that, there is also Formation of Tufa Banten (Pliestocene) with the lithology class of pyroclastic and alluvium sediment. This alluvium sediment consist of gravel, sand silt, and clay (semiunconsolidated).

A knowledge of rock density is necessary both for application of the Bouguer and terrain corrections and for the interpretation of gravity anomalies[14]. Based on the Quaternary rock map across the studied area, igneous and alluvium are dominant among other kind of rocks. Average density of alluvium is about $1920 \mathrm{~kg} / \mathrm{m}^{3}$. While igneous rocks such as basalt and andesite have a density range between 2400-3300 $\mathrm{kg} / \mathrm{m}^{3}$. Refer to those, in this study, density assumption used is in the range of 1700-3300 $\mathrm{kg} / \mathrm{m}^{3}$ to accomodate wide range of various rocks that may occur in the study area based on the existing geological map.

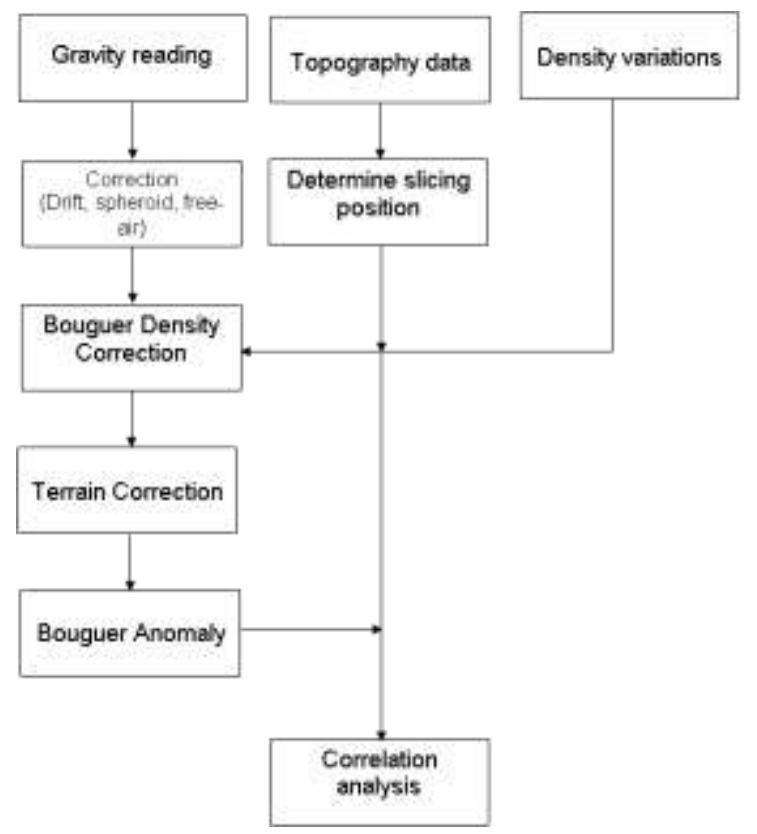

Figure 2 Work-Flow Diagram.

Data from gravity measurement serve as an input along with the topography data. Slicing positions are then determined based on the topography profile as shown in Figure 3. Three slice positions have been selected to analyze topografic profile and geological condition of the area, namely slice $\mathrm{A}-\mathrm{B}, \mathrm{A}-\mathrm{C}$ and A-D. Each slice represent different topography profile in order to analyze the effect of topography to Bouguer density. Slice A-B has a rough topography profile. The overall length covers $9.7 \mathrm{~km}$ which consist of 34 gravity data points. While slice $\mathrm{A}-\mathrm{C}$ has a length of $6,59 \mathrm{~km}$ and $2.88 \mathrm{~km}$ length of A-D slice.

Raw data from gravity measurement is corrected using the free air correction, drift correction and also spheroid correction which eventually produce the Bouguer density correction. Afterward, Bouguer anomaly is then calculated by using the value produce from Bouguer correction and Terrain correction. Figure 2 shows the general work flow diagram. Mathematical equation used to calculate the Bouguer anomaly, gBou, is as below [3]:

$$
g_{\text {Bou }}=F A A-\left(B C-\frac{T C}{\rho_{0}}\right) \cdot \rho
$$

FAA is free-air correction, while $\mathrm{BC}$ is Bouguer correction and $\mathrm{TC}$ is terrain correction. $\rho_{0}=2000 \mathrm{~kg} / \mathrm{m}^{3}$ and $\rho$ is the range of density assumption uses in this study.

Eq. (2) is applied on a certain slicing position. All slice is located in one line with different length. The overall length covers 9.7 $\mathrm{km}$ which consist of 34 gravity data points. While slice $\mathrm{A}-\mathrm{C}$ has a length of $6.59 \mathrm{~km}$ and $2.88 \mathrm{~km}$ length of A-D slice.

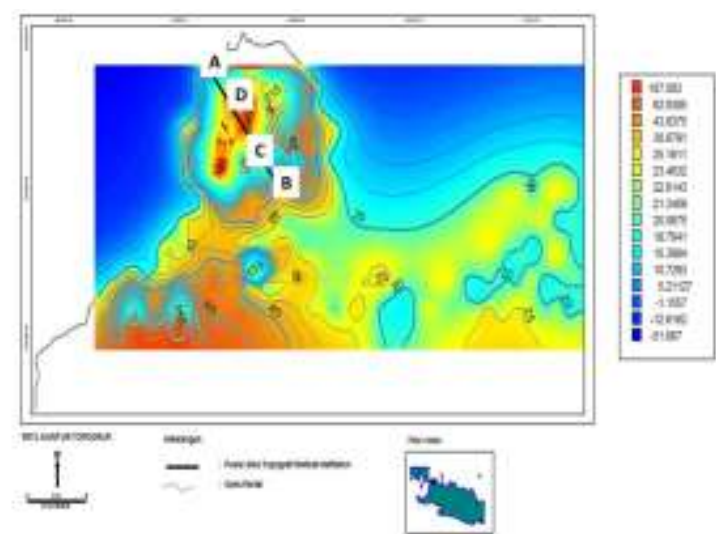

Figure 3 Topographic Profile and Slicing position of A,B,C,D for Nettleton Calculation[10].

After determining the slicing position, gBou for each rho is calculated using Eq. (2). Each gBou were grided using Golden Software Surfer. Correlation calculation is done by 
using "Correl" function which is available on Microsoft Excel.

\section{RESULT AND DISCUSSION}

By using the methodology explained previously, Table 1 and Figure 4 show the correlation value of Bouguer and topographic profile on $\mathrm{A}-\mathrm{B}$ slice which was created by using 34 data points, show that the average density could not be determined. This is due to the fact that $\mathrm{A}-\mathrm{B}$ slice is located on a region with hills and valleys which eventually resulting that light sediment effect is able to distort surface density value (Figure 6).

Table 1 Correlation Coefficient of Bouguer Anomaly on

\begin{tabular}{c|c}
\multicolumn{2}{|c}{ A-B Slice $[10]$} \\
\hline $\begin{array}{c}\text { Density Assumption } \\
\left(\mathrm{kg} / \mathrm{m}^{3}\right)\end{array}$ & $\begin{array}{c}\text { Correlation } \\
\text { Coefficient }\end{array}$ \\
\hline 1700 & -0.00733 \\
\hline 1800 & -0.08250 \\
\hline 1900 & -0.15628 \\
\hline 2000 & -0.22754 \\
\hline 2100 & -0.29533 \\
\hline 2200 & -0.35894 \\
\hline 2300 & -0.41791 \\
\hline 2400 & -0.47204 \\
\hline 2500 & -0.52131 \\
\hline 2600 & -0.56587 \\
\hline 2700 & -0.60597 \\
\hline 2800 & -0.64193 \\
\hline 2900 & -0.67410 \\
\hline 3000 & -0.70284 \\
\hline 3100 & -0.72852 \\
\hline 3200 & -0.75145 \\
\hline 3300 & -0.77194 \\
\hline &
\end{tabular}

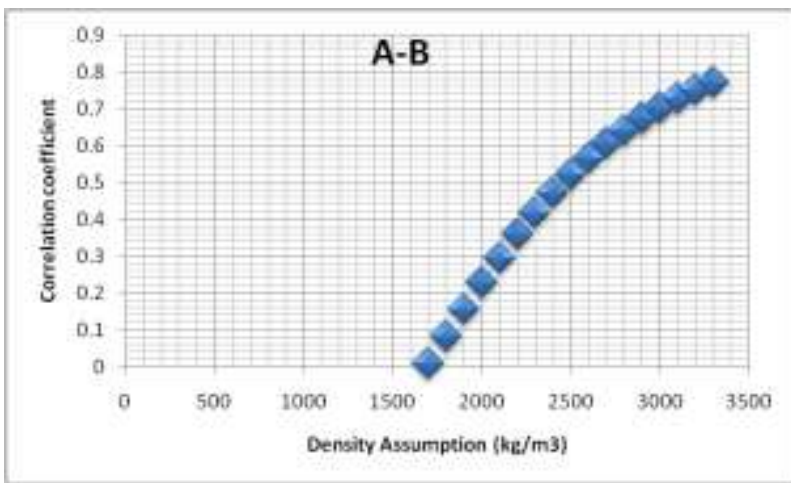

Figure 4 Correlation Coefficient and Density Assumption at A-B Slice.

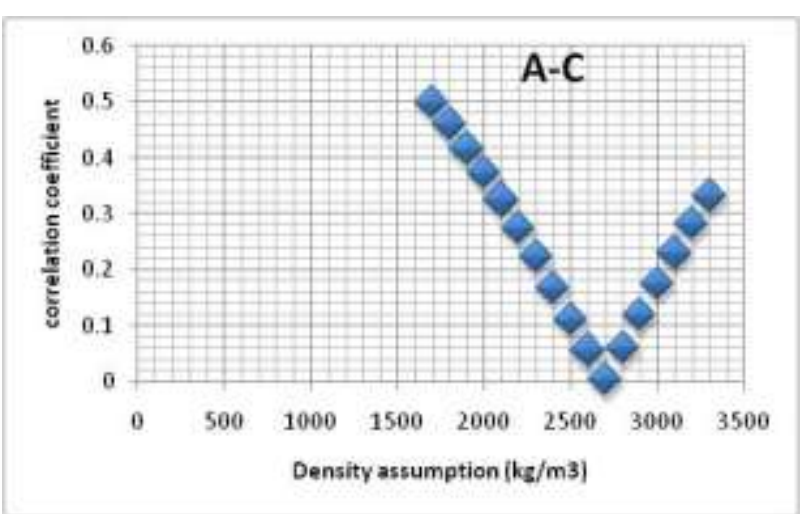

Figure 5 Correlation Coefficient and Density Assumption at A-C Slice.

Table 2 and Figure 5 show the correlation value of Bouguer and topographic profile on $\mathrm{A}-\mathrm{C}$ slice which was created by using 23 data points. The calculated correlation on $\mathrm{A}-\mathrm{C}$ slice showed that 2700 $\mathrm{kg} / \mathrm{m}^{3}$ as the density assumption would result lowest correlation value about 0.003 .

Table 3 and Figure 7 show the correlation value of Bouguer and topographic profile on $\mathrm{A}-\mathrm{D}$ slice which constitutes of 11 data points. The lowest correlation value of 0.248 was provided by the density assumption of $2300 \mathrm{~kg} / \mathrm{m}^{3}$.

From the above calculation, we can draw an analysis that both slices $\mathrm{A}-\mathrm{C}$ and $\mathrm{A}-$ $\mathrm{D}$ gives a relatively low correlation coefficient for different density assumption. Nevertheless, coefficient correlation between Bouguer anomaly and topographic profile of $\mathrm{A}-\mathrm{C}$ slice provide the lowest value. In accordance with that the density assumption for studied area using Nettleton method is $2700 \mathrm{~kg} / \mathrm{m}^{3}$. Based on the Quartenary rock map of the studied area, the value of Bouguer density of $2700 \mathrm{~kg} / \mathrm{m}^{3}$ could somehow interpret as the Quartenary rock of Upper Banten Tuff and Gede Mt. volcanic rocks.

At position A-B, the Nettleton has failed to predict Bouguer density value. Nettleton method work optimize at the area which have a topography condition that was not correlated with subsurface structure and high elevation variation. The Nettleton method can work only if there is no real gravity anomaly associated with the topography, and fail if, for example a hill is the surface expression of a dense igneous plug or a dipping limestone bed [15]. Further investigation using other method to 
confirm the existence of geological structure beneath it, should be performed.

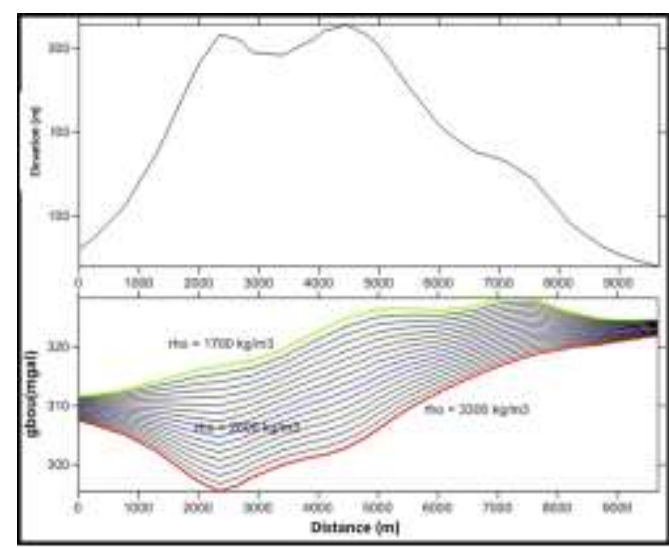

Figure 6 Topography Profile and Density Assumption at A-B Slice.

Table 2 Correlation Coefficient of Bouguer Anomaly Toward Topographic Profile of A-C Slice[10]

\begin{tabular}{c|c}
\hline $\begin{array}{c}\text { density assumption } \\
\left(\mathrm{kg} / \mathrm{m}^{3}\right)\end{array}$ & $\begin{array}{c}\text { Correlation } \\
\text { Coefficient }\end{array}$ \\
\hline 1700 & 0.4968145 \\
\hline 1800 & 0.4578452 \\
\hline 1900 & 0.416031 \\
\hline 2000 & 0.3713851 \\
\hline 2100 & 0.3239895 \\
\hline 2200 & 0.2740052 \\
\hline 2300 & 0.2216795 \\
\hline 2400 & 0.1673474 \\
\hline 2500 & 0.1114273 \\
\hline 2600 & 0.0544082 \\
\hline 2700 & -0.0031688 \\
\hline 2800 & -0.0607353 \\
\hline 2900 & -0.1177232 \\
\hline 3000 & -0.1735923 \\
\hline 3100 & -0.2278549 \\
\hline 3200 & -0.2800947 \\
\hline 3300 & -0.3299787 \\
\hline
\end{tabular}

Table 3 Correlation Coefficient of Bouguer Anomaly Toward Topographic Profile of A-D Slice[9]

\begin{tabular}{c|c}
\hline $\begin{array}{c}\text { Density Assumption } \\
\left(\mathrm{kg} / \mathrm{m}^{3}\right)\end{array}$ & $\begin{array}{c}\text { Correlation } \\
\text { Coefficient }\end{array}$ \\
\hline 1700 & 0.976896 \\
\hline 1800 & 0.967945 \\
\hline 1900 & 0.952731 \\
\hline 2000 & 0.924049 \\
\hline
\end{tabular}

\begin{tabular}{|c|c|}
\hline 2100 & 0.861655 \\
\hline 2200 & 0.69911 \\
\hline 2300 & 0.24884 \\
\hline 2400 & -0.42138 \\
\hline 2500 & -0.76476 \\
\hline 2600 & -0.88592 \\
\hline 2700 & -0.93488 \\
\hline 2800 & -0.95841 \\
\hline 2900 & -0.9713 \\
\hline 3000 & -0.97906 \\
\hline 3100 & -0.98407 \\
\hline 3200 & -0.98749 \\
\hline 3300 & -0.98993 \\
\hline
\end{tabular}

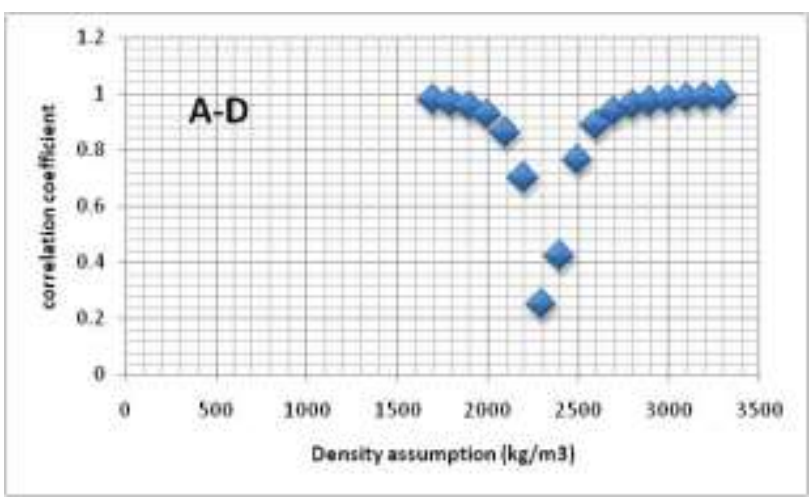

Figure 7 Coefficient and Density Assumption At A-D Slice.

\section{CONCLUSION}

In order to achieve accurate interpretation, gravity data processing requires several correction, Bouguer density correction is an essential step. By using data from Banten NPP site, Nettleton method has been applied to acquire Bouguer density correction.

Based on the calculation from three different slices position, it could be summarized that slice A-B which covers rough topography difference, Nettleton method has failed. While using the other two slices, Nettleton method yield with a different density value, $2700 \mathrm{~kg} / \mathrm{m}^{3}$ for $\mathrm{A}-\mathrm{C}$ and 2300 $\mathrm{kg} / \mathrm{m}^{3}$ for A-D. Based on the Quartenary rock map of the studied area, the value of Bouguer density of $2700 \mathrm{~kg} / \mathrm{m}^{3}$ could be interpreted as Banten Tuff and Gede Mt. volcanic rocks. 


\section{ACKNOWLEDGEMENT}

The author wishes to thank all of the colleagues at Center for Nuclear Energy System Assessment for the continuous encouragement and assistance in preparing the data.

\section{REFERENCES}

[1]. Lichoro, C., M. "Gravity and Magnetic Methods", Presented at Short Course IX on Exploration for Geothermal Resources, Lake Bogoria and Lake Naivasha, Kenya, Nov. 2-24, 2014.

[2]. D. Luo, et al., "A New Method of Gravity External Correction for High Precision Gravity Measurement", Journal of Applied Geophysics, Vol 109, pp. 301312, 2014.

[3]. LaFehr, T. R., Standardization in Gravity Reduction, Geophysics Vol. 56, No. 8. 1991

[4]. Telford et al. Applied GeophysicsSecond Edition. Cambridge University Press, Cambridge. 1990.

[5]. A. Yamamato, "Estimating the Optimum Reduction Density for Gravity Anomaly: A Theoretical Re view”, Journal Faculty of Science Hokkaido Univ., Ser. VII (Geophysics), Vol. 11, No.3, 577-599, 1999.

[6]. Toushmalani \& Rahmati, A new inversion method of estimation of simultaneous near surface bulk density variations and terrain across the Bandar Charak (Hormozgan-Iran), Springer Plus, 3:315. 2014.

[7]. Papp, G., Simultaneous determination of terrain correction and local average topographic density. Acta Geodaetica et Geophysica Hungarica 44:191-202. 2009.

[8]. Timothy Long, L., Douglas, R., Acquisition and Analysis of Terrestrial Gravity Data, Cambridge Press, 2013, pg. 104-105.

[9]. H. Gunawan, et. al, "Estimation of Bouguer Density Precision: Development of Method for Analysis of La Soufriere Volcano Gravity Data," J. Geol. Indones., vol. 3, no. 3, pp. 151-159, 2008.

[10]. Studi Analisis Multiskala Dalam Karakterisasi Sesar Kapabel di Provinsi Banten Menggunakan Data Citra Satelit, Gravity, Geolistrik, dan Magnetotellurik”, Tesis Program Magister Sains, Universitas Indonesia, Salemba, 2012

[11]. Sun, T. T. et al. Precious Opal from Java: Gemmological Properties, Microand Nano Structures. The Australian Gemmologist (2009) 23. 2009

[12]. E. Rusmana, et. al, "Peta Geologi Lembar Serang, Jawa”, P3GL, 1991.

[13]. M. A. Munir, et. al, "Miocene Bojongmanik Formation and its Potential as a Hydrocarbon Reservoir Rock in The Bogor Zone, Based On Outcrop Observations", Proceedings, Indonesian Petroleum Association Fortieth Annual Convention \& Exhibition, May 2016.

[14]. P. Kearey, et al. An Introduction to Geophysical Exploration. Blackwell Publishing, Third Edition, page 137. 2002

[15]. Milsom, J., Erikson, Aseger. Field Geophysics 4th Edition, Wiley, Oxford, UK. 2011. 
HALAMAN INI SENGAJA DIKOSONGKAN 